\title{
GOOD CORPORATE GOVERNANCE DAN UKURAN PERUSAHAAN PENGARUHNYA PADA TAX AVOIDANCE
}

\author{
Vivi Adeyani Tandean \\ Institut Bisnis dan Informatika Kwik Kian Gie \\ e-mail: vivi.tandean@gmail.com
}

\begin{abstract}
ABSTRAK
Penelitian ini bertujuan untuk menguji secara empiris pengaruh penerapan GCG dan ukuran perusahaan pada tax avoidance. Penelitian ini dilakukan pada perusahaan manufaktur yang terdaftar di BEI periode 20102013. Variabel yang digunakan adalah kepemilikan institusional, independensi auditor, komite audit, dan ukuran perusahaan sebagai variabel independen serta tax avoidance sebagai variabel dependen. Sampel penelitian ini 84 perusahaan manufaktur. Teknik pengambilan sampel menggunakan judgment sampling. Pengujian data menggunakan analisis regresi berganda. Hasil pengujian menunjukan bahwa hanya komite audit berpengaruh pada tax avoidance.
\end{abstract}

Kata kunci: Corporate governance, size,tax avoidance

\begin{abstract}
This study aims to examine empirically the effect of the application of GCG and the size of the company on tax avoidance. This study was performed on companies listed on the Stock Exchange 2010-2013. Variables used are institutional ownership, the independence of auditors, the audit committee, and the size of the company as an independent variable and tax avoidance as the dependent variable. The research sample 84 manufacturing companies. The sampling technique using judgment sampling. Testing data using multiple regression analysis. The test results showed that only affects the audit committee on tax avoidance.
\end{abstract}

Keywords: Corporate governance, size, tax avoidance

\section{PENDAHULUAN}

Pajak merupakan unsur penting dalam menopang penerimaan negara. Dilain pihak, pajak ditempatkan sebagai salah satu kewajiban dalam bernegara, yaitu sebagai sarana masyarakat untuk ikut berpartisipasi dalam rangka membantu pelaksanaan tugas bernegara yang ditangani oleh pemerintah. Upaya mengoptimalkan penerimaan sektor pajak dilakukan melalui usaha intensifikasi dan eksentifikasi penerimaan jumlah pajak. Kendala utama dalam rangka penerimaan pajak adalah penggelapan pajak (tax evasion) dan penghindaran pajak (tax avoidance). Penghindaran pajak merupakan upaya untuk meminimalkan beban pajak menggunakan peraturan yang berlaku (lawful) sedangkan penggelapan pajak merupakan upaya melakukan penghematan pajak dengan menggunakan cara - cara yang melanggar ketentuan pajak. Pemerintah mengharapkan adanya sikap taat pajak dari seluruh masyarakat yang merupakan wajib pajak. Sikap taat pajak dalam arti bahwa wajib pajak selalu membayar pajak seusai dengan kondisi yang sebenarnya.
Berbeda degan perusahaan yang memiliki tujuan dalam memaksimalkan laba agar nilai saham perusahaan dapat meningkat dan perusahaan semakin diminati oleh para investor. Perbedaan kepentingan ini yang menyebabkan perusahaan berusaha untuk membayar pajak seminimal mungkin dengan melakukan manajemen pajak tanpa melanggar undang - undang. Tuntutan bagi perusahaan dalam melakukan manajemen pajak yang harus diawasi menjadikan dibentuknya corporate governance yang diharapkan dapat mendorong terwujudnya transparansi, accountability, responsibility, independency dan fairness (Winarsih dkk., 2014). Faktor - faktor GCG yang digunakan dalam penelitian ini adalah kepemilikan institusional, independensi auditor dan komite audit. Selain itu ukuran perusahaan digunakan untuk mendeteksi penghindaran pajak. Bauran aset yang dimiliki oleh perusahaan juga dapat berpengaruh terhadap kesempatan perusahaan melakukan penghindaran pajak. 
Penelitian ini menggunakan agency theory yang mengasumsikan bahwa setiap manusia memiliki sifat egois. Scott (2003:305) mengatakan bahwa agency theory adalah perkembangan teori yang mempelajari bagaimana merancang kesepakatan kerja agar dapat memotivasi para agen untuk bekerja sesuai dengan keinginan prinsipal. Teori keagenan juga mengimplikasikan adanya asimetri informasi antara manajer sebagai agen dan dan pemilik sebagai prinsipal. Manajemen sebagai pengelola perusahaan lebih banyak mengetahui informasi internal sehingga terdapat kesenjangan atau gap akan luasnya informasi yang dimiliki oleh manajemen dengan pemilik. Oleh karena itu sebuah keputusan tidak akan pernah memuaskan pihak agen dan prinsipal secara bersama-sama dan kedua belah pihak tidak akan benar-benar setuju untuk melakukan tindakan tersebut bila tidak ada kontrak yang mengikatnya. Permasalahan keagenan dimana terdapat perbedaan kepentingan bagi agen dan prinsipal memicu timbulnya perilaku aggresive tax avoidance. Hal ini dikarenakan di satu sisi manajemen menginginkan peningkatan kompensasi melalui laba yan tinggi sedangkan sisi lainnya pemegang saham ingin menekan biaya pajak melalui laba yang rendah. Maka dalam rangka menjembatani agency problem ini timbul perilaku aggresive tax avoidance dalam rangka mengoptimalkan kedua kepentingan tersebut.

Menurut Hary Graham Balter dalam Zain (2005:49) mengatakan bahwa tax avoidance merupakan uasaha yang dilakukan oleh wajib pajak - apakah berhasil atau tidak untuk mengurangi atau sama sekali menghapus utang pajak, yang tidak melanggar ketentuan peraturan perundang-undangan perpajakan. Sedangkan Anderson dalam Zain (2005:50) menyatakan bahwa penghindaran pajak adalah cara mengurangi pajak yang masih dalam batas ketentuan peraturan perundang-undangan perpajakan dan dapat dibenarkan, terutama melalui perencanaan pajak. Tindakan untuk menurunkan laba kena pajak ini merupakan situasi ketika perusahaan melakukan kebijakan pajak tertentu dan suatu hari terdapat kemungkinan tindakan pajak tersebut tidak akan diaudit atau dipermasalahkan dari sisi hukum, namun tindakan ini beresiko karena ketidakjelasan posisi akhir, apakah tindakan pajak tersebut dianggap melanggar atau tidak melanggar hukum yang berlaku. Hite dan McGill dalam Sari dan Martani (2010). Pemilik perusahaan akan cenderung lebih menyukai apabila perusahaan melakukan tindakan aggresive tax avoidance karena pajak merupakan biaya bagi perusahaan dan pemilik perusahaan (Chen et al.,2008).
Tax avoidance dibedakan menjadi penghindaran pajak yang diperbolehkan (acceptabel tax avoidance) dan yang tidak diperbolehkan (unacceptabel tax avoidance). Perbedaan antara kedua jenis tax avoidance ini seperti yang diungkapkan oleh Slamet dan Rusydi dan Mantani (2014) adalah ada atau tidaknya tujuan usaha yang baik, apakah tindakan sesuai dengan jiwa undang undang dan maksud dari pemerintah serta apakah melakukan transaksi yang direkayasa. Komite urusan fiskal dari Organization for Economic Cooperation and Development (OECD) dalam Suandy (2008:7) menyebutkan bahwa terdapat tiga karakter dalam penghindaran pajak, yaitu: 1) Adanya unsur artifisial dimana berbagai pengaturan seolaholah terdapat di dalamnya padahal tidak, dan ini dilakukan karena ketiadaan faktor pajak; 2) Skema semacam ini sering memanfaatkan loopholes dari undang-undang atau menerapkan ketentuanketentuan legal untuk berbagai tujuan, padahal bukan itu yang sebetulnya dimaksudkan oleh pembuat undang-undang; dan 3) Kerahasiaan juga sebagai bentuk dari skema ini dimana umumnya para konsultan menunjukkan alat atau cara untuk melakukan penghindaran pajak dengan syarat wajib pajak menjaga serahasia mungkin.

Sartori (2008:12) menegaskan bahwa konsep tax avoidance merupakan sebuah konsep terhadap perlindungan pajak. Pengertian secara luas mengenai konsep ini adalah sebuah transaksi atau perjanjian yang dirancang untuk mengurangi atau menunda perpajakan dengan cara-cara tertentu.

GCG merupakan tata kelola yang baik pada suatu usaha yang dilandasi oleh etika profesional dalam berusaha. Pemahaman GCG merupakan wujud penerimaan akan pentingnya suatu perangkat peraturan atau tata kelola yang baik untuk mengatur hubungan, fungsi dan kepentingan berbagai pihak dalam urusan bisnis. KNKG (2006) menyatakan bahwa setiap perusahaan harus memastikan bahwa asas GCG diterapkan pada setiap aspek bisnis dan di semua jajaran perusahaan. Asas GCG yaitu transparansi, akuntabilitas, responsibilitas, independensi serta kewajaran dan kesetaraan diperlukan untuk mencapai kesinambungan usaha (sustainability) perusahaan dengan memperhatikan para pemangku kepentingan (stakeholders). Asas-asas ini harus dipastikan berada dalam perusahaan karena prinsip corporate governance dapat mempengaruhi pengambilan keputusan perpajakan perusahaan, terutama pada prinsip transparansi. Dengan adanya keterbukaan informasi diharapkan perusahaan akan 
cenderung mengambil tindakan perpajakan yang tidak beresiko dengan tidak melakukan tax avoidance (Sari dan Martani, 2010).

Kepemilikan institusional adalah proporsi kepemilkan saham yang dimiliki oleh pemilik institusi dan blockholder pada akhir tahun (Wahyudi dan Pawestri dalam Simarmata dan Cahyonowati, 2014). Kepemilikan institusioanl ini memiliki pengaruh yang penting bagi perusahaan dalam memonitor manajemen, karena akan mendorong peningkatan pengawasan yang lebih optimal sehingga mempengaruhi tindakan tax avoidance. Chen et al. (2008) mengindikasikan bahwa perusahaan non keluarga memiliki tingkat keagresifan terhadap penghindaran pajak yang lebih tinggi dibandingkan dengan perusahaan keluarga. Hal ini disebabkan oleh perusahaan keluarga sangat menjaga reputasi dan nama baik sehingga perusahaan keluarga tidak mau mengambil resiko untuk melakukan tax avoidance. Semakin besar kepemilikan institusional yang dimiliki oleh pendiri perusahaan, maka semakin kecil kebijakan pajak agresif karena pemilik institusional sangat memperhatikan dampak jangka panjang yang akan dihasilkan terhadap tindakan pajak agresif (Zemzem dan Ftouhi, 2013).

Independensi dalam audit berarti mengambil sudut pandang yang tidak biasa dalam melakukan pengujian audit, evaluasi atas hasil pengujian dan penerbitan laporan audit (Radal J. Elder, Marks S. Beasley, Alvin A. Arens, dan Amir Abadi Yusuf 2011). Seorang auditor tidak hanya dituntut untuk kompeten dalam melaksanakan tugasnya, tetapi yang paling penting seorang auditor juga harus memiliki sikap yang independen. Para auditor berusaha keras untuk mempertahankan sikap independensinya untuk menjaga kepercayaan para pengguna laporan keuangan. Untuk menjaga independensi auditor maka Bapepam-LK mengadopsi peraturan-peraturan Sarbanes-Oxley. Peraturan ini membatasi kemungkinan auditor memberikan jasa non-audit pada klien auditnya, dan juga tentang pembatasan lama kerja KAP dan auditor, serta mengharusnya adanya rotasi partner audit untuk meningkatkan independensi. Peraturan tentang pergantian ini sudah muncul pada tahun 2002 dalam bentuk keputusan Menteri Keuangan. Dalam pasal 59 ayat 6 Keputusan Menteri Keuangan No.423 tahun 2002 tersebut mengatakan bahwa: Akuntan Publik yang telah memberikan jasa audit umum untuk 3 (tiga) tahun buku berturut - turut atau lebih dan masih mempunyai perikatan audit umum untuk satu tahun buku berikutnya atas laporan keuangan dari suatu entitas pada saat berlakunya Keputusan Menteri Keuangan ini, hanya dapat melaksanakan perikatan dimaksud untuk 1 (satu) tahun buku berikutnya. Hal ini disebut rotasi auditor. Rotasi auditor terjadi karena auditee mengikuti peraturan dari pemerintah yang membatasi hubungan antara auditee dan auditor selama jangka waktu tertentu. Hal ini dilakukan supaya auditor dapat menjaga independensinya karena independensi auditor dapat diragukan dalam memberikan opini audit apabila auditor terlalu lama memebrikan jasa audit kepada satu perusahaan. Sehingga diperlukan rotasi auditor. Transparansi dalam nemapilkan laporan keuangan merupakan elemen penting dalam GCG terkait dengan hal-hal perpajakan yang dipertanggungjawabkan kepada pemegang saham. Dikarenakan peningkatan transparansi terhadap pemegang saham dalam hal pajak semakin dituntut oleh otoritas public (Sartori, 2008) sehingga pemegang saham tidak menyukai bila perusahaan berada dalam tindakan pajak agresif dan akan mencegah tindakan tersebut. Oleh karena itu independensi auditor yang dilakukan dengan rotasi auditor diyakini mampu menunjukkan apabila terjadi tindakan tax avoidance dalam perusahaan.

Komite audit adalah komite yang dibentuk oleh dan bertanggung jawab kepada Dewan Komisaris dalam membantu melaksanakan tugas dan fungsi Dewan Komisaris. Komite audit diketuai oleh Komisaris Independen dan anggotanya dapat terdiri dari Komisaris dan atau pelaku profesi dari luar perusahaan. Anggota komite audit diangkat dan diberhentikan oleh dewan komisaris (BAPEPAMLK, 2012). Tanggungjawab komite audit dalam bidang corporate governance adalah untuk memastikan bahwa perusahaan telah dijalankan sesuai undangundang dan peraturan yang berlaku, melaksanakan usahanya dengan beretika, melaksanakan pengawasannya secara efektif terhadap benturan kepentingan dan kecurangan yang dilakukan oleh karyawan perusahaan. Dengan terbentuknya komite audit menjadikan performa auditor menjadi lebih independen dikarenakan praktek kolusi antara manajemen dengan auditor menjadi lebih sulit untuk dilakukan (Watts dan Zimmerman, 1983).

Ukuran perusahaan adalah suatu skala dimana dapat diklasifikasikan besar kecil perusahaan menurut beberapa cara, antara lain: total asset, penjualan bersih dan kapitalisasi pasar. Perusahaan yang memiliki total aktiva besar menunjukkan bahwa perusahaan tersebut telah mencapai tahap kedewasaan dimana dalam tahap ini arus kas perusahaan sudah positif dan dianggap memiliki prospek yang baik dalam jangka 
waktu yang relatif lama. Sehingga perusahaan yang diklasifikasikan sebagai perusahaan besar cenderung meminimalkan tindakan pajak agresif karena ketatnya pengawasan oleh otoritas publik.

Ha1: kepemilikan institusional berpengaruh terhadap tax avoidance.

Ha2: independensi auditor berpengaruh terhadap tax avoidance.

Ha3: komite audit berpengaruh terhadap tax avoidance.

Ha4: ukuran perusahaan berpengaruh terhadap tax avoidance.

\section{METODE PENELITIAN}

Penelitian ini bertujuan untuk melihat pengaruh good corporate governance yang diproksikan dengan kepemilikan institusional, komite audit, independensi auditor dan ukuran perusahan terhadap tax avoidance pada perusahaan manufaktur yang terdaftar di Bursa Efek Indonesia tahun 2010 - 2013 yang berjumlah 84 perusahaan. Penelitian ini menggunakan data sekunder berupa annual report dan audited report. Data yang berhubungan dengan informasi perusahaan yang dibutuhkan bagi penelitian ini diperoleh dari www.idx.co.id, dan ICMD. Dalam penelitian ini teknik yang digunakan untuk mengambil sampel adalah metode purposive sampling dengan cara judgment sampling. Pemilihan sampling menggunakan metode judgement sampling bertujuan untuk memperoleh sampel yang representative berdasarkan kriteria tertentu.

Variabel bebas (independent variabel) yang digunakan dalam penelitian ini adalah good corporate governance dimana mekanismenya diukur dengan: 1). Kepemilikan institusional adalah proporsi kepemilikan saham yang dimiliki oleh pemilik institusi dan blockholders pada akhir tahun yang diukur menggunakan persentase. 2). Independensi auditor merupakan variabel dummy, jika perusahaan sampel melakukan pergantian auditor selama periode pengamatan maka diberi nilai 1 , jika perusahaan sampel tidak melakukan pergantian auditor maka diberi nilai 0.3). Komite audit merupakan jumlah anggota komite audit dalam perusahaan sampel yang dijadikan sebagai alat ukur dilakukannya corporate governance. 4). Ukuran Perusahaan (UKP) diukur dengan menggunakan hasil logaritma natural dari total aset perusahaan. Total aset digunakan sebagai proksi ukuran perusahaan dengan pertimbangan total aset perusahaan relatif lebih stabil dibandingkan dengan jumlah penjualan dan nilai kapitalisasi pasar (Guna dan Herawaty, 2010) dan 5). Variabel terikat (dependent variable) yang digunakan dalam penelitian ini adalah tax avoidance yang diukur menggunakan current ETR. Current ETR dihitung dengan membandingkan pajak kini (current tax) dengan laba sebelum pajak penghasilan (pre-tax income). Pajak kini terdapat dalam Laporan Laba Rugi pada pos "manfaat (beban) pajak penghasilan" sedangkan laba perusahaan sebelum pajak terdapat pada pos "laba sebelum pajak penghasilan". Hanlon dan Heitzman (2010) menghitung current ETR sebagai berikut:

$$
\text { Current ETR }=\frac{\text { current tax expense }}{\text { pre-tax income }}
$$

Teknik analisis data yang digunakan untuk menguji hipotesis penelitian ini adalah statistik deskriptif, uji asumsi klasik yang meliputi uji normalitas, uji autokorelasi, uji multikolonieritas dan uji heterokedastisitas. Selanjutnya untuk menguji pengaruh dua atau lebih variabel bebas terhadap variabel terikat digunakan analisis regresi berganda (multiple regression analysis) dengan menggunakan SPSS versi 22. Analisa regresi berganda juga mengukur kekuatan hubungan antara dua variabel atau lebih, serta menunjukkan arah hubungan antara variabel dependen dan variabel independen. Adapun persamaan untuk menguji hipotesis secara keseluruhan pada penelitian ini adalah sebagai berikut:

$\mathrm{Y}=\mathrm{b} 0+\mathrm{b} 1 \mathrm{X} 1+\mathrm{b} 2 \mathrm{X} 2+\mathrm{b} 3 \mathrm{X} 3+\mathrm{b} 4 \mathrm{X} 4+\mathrm{e}$

Keterangan :

$\mathrm{Y} \quad=$ tax avoidance

$\mathrm{b} 0 \quad=$ konstanta

$\mathrm{X} 1=$ kepemilikan institusional

$\mathrm{X} 2=$ independensi auditor

$\mathrm{X} 3=$ komite audit

$\mathrm{X} 4=$ ukuran perusahaan

$\mathrm{e} \quad=$ error

Ketepatan fungsi regresi sampel dalam menaksir nilai aktual dapat diukur dari model Goodness of Fit fungsi regresi tersebut. Secara statistik pengujian hipotesis ini dapat diukur dari nilai koefisien determinasi (Adjusted R2), nilai statistik F dan nilai statistik t. Perhitungan statistik signifikansi apabila nilai uji statistik berada dalam daerah kritis, yaitu daerah dimana $\mathrm{H} 0$ ditolak dan menjadi tidak signifikan bila nilai uji statistik berada dalam daerah H0 diterima. 


\section{HASIL DAN PEMBAHASAN}

Berdasarkan hasil analisis deskriptif pada Tabel 1 (Lampiran 1) menunjukkan bahwa jumlah data yang digunakan dalam penelitian ini berjumlah 84 perusahaan. Variabel dependen current ETR menunjukkan nilai minimum sebesar 0,00404 yang mengindikasikan semakin kecilnya peluang terjadinya tax avoidance. Sedangkan nilai maksimum sebesar 0,40822 mengindikasikan tingginya kemungkinan terjadinya tax avoidance. Nilai rata - rata current ETR pada penelitian ini sebesar 0.2277489 yang menunjukkan bahwa potensi terjadinya tax avoidance pada perusahaan cukup tinggi. Variabel independen dalam analisis deskriptif ini, yaitu kepemilikan institusional memiliki rata - rata sebesar 0,7236366 yang berarti kepemilikan perusahaan oleh pihak institusi rata - rata sebesar $72,36 \%$ dengan persentase paling minimum berjumlah 0,29704 atau $29,70 \%$ dan kepemilikan instituisional tertinggi sebesar 0,96210 atau $96,21 \%$ dari saham perusahaan beredar yang dimiliki oleh institusi. Variabel independensi auditor memiliki nilai minimum 0 dan nilai maksimum 1 sedangkan nilai rata - ratanya sebesar 0,4099348. Hal ini berarti bahwa rata - rata perusahaan sampel bersifat independen dengan mengganti auditornya dalam kurun waktu kurang dari 3 tahun telah mematuhi peraturan Bapepam bahwa pemberian jasa audit oleh seorang akuntan paling lama 3 tahun buku berturut - turut. Variabel ukuran komite audit memiliki nilai minimum sebesar 2 orang dan nilai maksimum sebesar 4 orang. Nilai rata - rata variabel ini adalah sebesar 3,07 yang berarti bahwa rata rata perusahaan sampel memiliki anggota komite audit sebanyak 3 orang. Variabel ukuran perusahaan memiliki nilai minimum sebesar 25,22110 dan nilai maksimum sebesar 30,36220. Sedangkan nilai ratarata variabel ini adalah 27,8132821.

Berdasarkan hasil pengujian normalitas pada Tabel 2 (Lampiran 2) yang menunjukkan nilai probabilitas signifikansi data residual sebesar 0,101 $>\alpha=0,05$ maka tidak tolak Ho yang berarti bahwa nilai residual variabel terdistribusi secara normal.

Berdasarkan hasil uji autokorelasi pada Tabel 3 (Lampiran 3) nilai Durbin-Watson memperlihatkan angka 2,050 yang merupakan $\mathrm{du}<\mathrm{d}<4$-du sehingga dapat dinyatakan bahwa model regresi terbebas dari masalah autokorelasi (tidak tolak Ho). Dimana du adalah nilai batas atas tabel Durbin-Watson sebesar 1,7462 dengan $\alpha=0,05, n=84$ dan $k=4$. Sedangkan berdasarkan pengujian runs test menunjukkan nilai $\operatorname{sig}(2$-tailed) $>0,05$ sehingga tidak terjadi autokorelasi.
Berdasarkan hasil uji multikolonieritas pada Tabel 4 (Lampiran 4) menunjukkan seluruh nilai VIF $<10$ dan nilai tolerance seluruhnya $\geq 0,10$. Hal ini menyatakan bahwa tidak terjadi multikolonieritas pada model regresi ini.

Berdasarkan hasil uji heterokedastisitas pada Tabel 5 (Lampiran 5) dengan menggunakan metode park menunjukkan koefisien beta tidak signifikan secara statistik dimana nilai signifikannya $>0,05$. Berdasarkan hal tersebut maka model empiris tersebut homokedastisitas (tidak tolak Ho).

Berdasarkan hasil uji koefisien determinasi pada Tabel 6 (Lampiran 6) menunjukkan nilai adjusted $\mathrm{R}^{2}$ sebesar 0,080 yang berarti variabel tax avoidance dapat dijelaskan oleh variabel kepemilikan institusional, independensi auditor, komite audit dan ukuran perusahaan sebesar $8 \%$ sedangkan sisanya sebesar $92 \%$ dijelaskan oleh variabel lain yang tidak digunakan dalam penelitian ini.

Berdasarkan hasil regresi liner berganda pada Tabel 7 (Lampiran 7) maka hasil regresi dapat diperoleh persamaan regresi sebagai berikut :

ETR $=-0,053+0,063$ INST $-0,013$ INDP + $0,059 \mathrm{KOMITE}+0,003$ SIZE.

Keterangan :

ETR = Current ETR

INST = Kepemilikan Institusional

INDP = Independensi auditor

Komite $=$ Komite audit

Size = Ukuran Perusahaan

Persamaan regresi tersebut memiliki nilai konstanta sebesar -0,053 yang menunjukkan besarnya current ETR adalah sebesar 5,3\% jika seluruh variabel independen bernilai 0. Persamaan tersebut menunjukkan besar kekuatan variabel independen dalam mempengaruhi variabel dependen yang ditunjukkan dari besar koefisien masing masing variabel independen.

Berdasarkan hasil uji regresi berganda dapat digunakan untuk penjabaran dari hasil uji statistik $\mathrm{t}$ bagi pengaruh masing - masing variabel independen terhadap variabel dependen. Koefisien regresi untuk kepemilikan institusional sebesar 0,063 degan nilai signifikan $\mathrm{t}$ sebesar $0,095>\alpha=0,05$. Hasil ini menunjukkan bahwa kepemilkan institusional tidak berpengaruh terhadap tax avoidance (tidak tolak Ho). Semakin besar kepemilikan institusioanl dalam perusahaan akan mengurangi tindakan tax avoidance dikarenakan adanya tanggung jawab perusahaan kepada para pemegang saham. Penyebab kepemilikan institusional tidak berpengaruh signifikan terhadap tax avoidance diduga karena 
pemilik institusional tidak berperan serta dalam memantau, mendisiplinkan dan mempengaruhi tindakan oportunis manajer. Penyebab lainnya diduga karena pemilik institusional lebih mementingkan untuk memaksimalkan kesejahteraannya dalam laba yang akan mereka peroleh sehingga besar atau kecilnya kepemilikan institusional tidak mempengaruhi tax avoidance.

Koefisien regresi untuk independensi auditor adalah -0,013 dengan nilai signifikan t sebesar 0,786 $>\alpha=0,05$. Hasil ini menunjukkan bahwa independensi auditor tidak berpengaruh terhadap tax avoidance (tidak tolak Ho). Adanya regulasi pemerintah mengenai rotasi audtor setiap tiga tahun sekali untuk menjaga independensi auditor dari tindakan oportunis manajer perusahaan. Dilain pihak tuntutan yang tinggi dan kepercayaan masyarakat terhadap auditor menyebabkan keberadaan auditor diharapkan memberikan pendapat (opini) yang sebenarnya tentang kondisi perusahaan kepada masyarakat. Sehingga auditor juga harus menjaga independensinya untuk mempertahankan reputasinya. Koefisien regresi untuk komite audit sebesar 0,059 dengan nilai signifikan $\mathrm{t}$ sebesar $0,026<\alpha=0,05$. Hasil ini menunjukan bahwa komite audit berpengaruh terhadap tax avoidance secara signifikan (tolak Ho). Komite audit berjumlah sekurang - kurangnya tiga orang dimana salah satunya merupakan komisaris independen perusahaan dan bertindak sebagai ketua komite audit (BAPEPAMLK, 2012). Jika jumlah komite audit kurang dari tiga orang, maka akan mengingkatkan tindakan manajemen dalam melakukan minimalisasi laba untuk kepentingan pajak (Pohan dalam Fadhilah, 2014). Semakin banyak jumlah komite audit dalam perusahaan maka pengendalian kebijakan keuangan akan semakin ketat sehingga sulit untuk dilakukannya tax avoidance.

Koefisien regresi untuk ukuran perusahaan sebesar 0,003 dengan nilai signifikan t sebesar 0,669 $>\alpha=0,05$. Hasil ini menunjukkan bahwa ukuran perusahaan tidak berpengaruh terhadap tax avoidance (tidak tolak Ho). Besar kecilnya ukuran perusahaan tidak mempengaruhi tindakan oportunis manajer untuk melakukan tax avoidance. Karena perusahaan beranggapan bahwa pajak yang dibayarkan adalah beban yang akan mengurangi laba yang diharapkan. Sehingga perusahaan memanfaatkan loopholes yang ada untuk melakukan tax avoidance.

Berdasarkan hasil uji $\mathrm{F}$ menunjukkan angka signifikansi sebesar $0,031<\alpha=0,05$. Hasil ini menunjukkan bahwa secara simultan variabel independen dalam model penelitian ini berpengaruh secara signifikan terhadap variabel dependen sehingga Ho ditolak. Dengan kata lain bahwa variabel kepemilkan institusional, independensi auditor, komite audit dan ukuran perusahaan secara simultan merupakan penjelas yang signifikan terhadap variabel tax avoidance.

\section{KESIMPULAN}

Setelah melakukan pengujian atas penelitian yang telah dilakukan menghasilkan kesimpulan bahwa keberadaan komite audit berpengaruh secara signifikan tehadap tax avoidance sehingga semakin banyak jumlah komite audit maka akan mengurangi tindakan tax avoidance. Hasil penelitian ini sesuai dengan hipotesis yang dikemukakan dalam penelitian ini. Sedangkan kepemilkan institusional, independensi auditor dan ukuran perusahaan tidak berpengaruh dalam mengurangi tindakan tax avoidance dan tidak sesuai dengan hipotesis yang dikemukakan dalam penelitian ini. Variabel kepemilikan institusional, independensi auditor, komite audit dan ukuran perusahaan secara bersama - sama berpengaruh terhadap tax avoidance.

\section{DAFTAR REFERENSI}

Annisa, Nuralifmida Ayu dan Lulus Kurniasih. 2012. Pengaruh Corporate Governance terhadap Tax Avoidance, Jurnal Akuntansi \& Auditing, Mei Vol. 8, Universitas Sebelas Maret, Surakarta.

Cooper, Donald R. dan Pamela S. Schindler. 2006. Metode Riset Bisnis, Edisi 9, Terjemahan oleh Budijanto, Didik Djunaedi \& Damos Sihombing, Jakarta, Penerbit PT. Media Global Edukasi.

Fahilah, ramli. 2014. Pengaruh Good Corporate Governance Terhadap Tax Avoidance, Jurnal Universitas Negeri Padang.

Ghozali, Imam. 2009. Aplikasi Analisis ultivariate dengan Program SPSS, Edisi 4, Semarang: Badan Penerbit Universitas Diponegoro.

Hanlon, Michelle dan Shane Heitzman. 2010. A Review of Tax Research, Journal of Accounting and Economics 50, pp 127 - 178.

Irawan, Hendara Putra dan Aria Farahmita. 2014. Pengaruh Kompensasi Manajemen dan Corporate Governance terhadap Manajemen Pajak perusahaan, Universitas Indonesia, Depok.

Jensen, Michael C. dan William H. Meckling. 1976. Theory of The Firm : managerial Behaviour, 
Agency Costs and Ownership Structure, Journal of Financial Econominc Vol. 3, No. 4 pp. 305 -360.

Komite Nasional Kebijakan Governance (KNKG). 2006.

Pedoman Umum Good Corporate Governance Indonesia, Jakarta.

Mayangsari, Sekar. 2003. Analisis Pengaruh Independensi, Kualitas Audit Serta Mekanisme Corporate Governance Terhadap Integritas Laporan Keuangan, Simposium Nasional Akuntansi VI, 16-17 Oktober, Surabaya.

Rusydi, M. Khoiru dan Dwi Martani. 2014. Pengaruh Struktur Kepemilikan Terhadap Aggressive Tax Avoidance, Simposium Nasional Akuntansi XVII, 24-27 September, Mataram.

Sartori, Nicola. 2008. Effect of Strategic Tax Behaviours on Corporate Governance, Social Science Research Network

Scott, William R. 2003. Financial Accounting Theory, Edisi 3, Toronto : Prentice Hall.

Suandy, Erly. 2008. Perencanaan Pajak, Edisi 4, Jakarta: Salemba Empat.
Republik Indonesia. 2007. Undang - Undang No. 28 tahun 2007 Tentang Ketentuan Umum dan Tata Cara Perpajakan. Lembaran Negara RI Tahun 2007, No. 85. Sekretariat Negara, Jakarta.

Waluyo. 2013. Perpajakan Indonesia, Edisi 11, Jakarta : Salemba Empat.

Watts, Ross L. dan Jerold L. Zimmerman.,1983. Agency Problems, Auditing and The Theory of The Firm : Some Evidence, Journal of Law and Economics, Vol. 26, No. 3, pp. 613-633.

Zain, Mohammad. 2005. Manajemen Perpajakan, Jakarta : Salemba Empat.

Zemzem, Ahmed dan Khaoula Ftouhi. 2013. The Effects of Board of Directors Characteristics on Tax Aggressiveness, Journal of Finance and Accounting, Vol. 4, no. 4.

\section{Lampiran}

Tabel 1. Analisis Deskriptif

\begin{tabular}{|l|r|r|r|r|r|}
\hline & $\mathrm{N}$ & Minim um & M aximum & \multicolumn{1}{c|}{ Mean } & \multicolumn{1}{c|}{ Std. Deviation } \\
\hline ETR_y & 84 &, 00404 &, 40822 &, 2277489 &, 06860799 \\
INST_x1 & 84 &, 29704 &, 96210 &, 7236366 &, 19416185 \\
INDP_x2 & 84 &, 00000 & 1,00000 &, 4099348 &, 15595391 \\
KOMITE_x3 & 84 & 2 & 4 & 3,07 &, 302 \\
SIZE_x4 & 84 & 25,22110 & 30,36220 & 27,8132821 & 1,30073533 \\
Valid N (listwise) & 84 & & & & \\
\hline
\end{tabular}

Tabel 2.

Hasil Uji Normalitas

One-Sample Kolmogorov-Smirnov Test

\begin{tabular}{|ll|r|}
\hline & & $\begin{array}{r}\text { Unstandardized } \\
\text { Residual }\end{array}$ \\
\hline N & Mean & 84 \\
Normal Parameters & a,b & Std. Deviation \\
& Absolute &, 06617117 \\
Most Extreme Differences & Positive &, 133 \\
& Negative &, 080 \\
Kolmogorov-Smirnov Z & &,- 133 \\
Asymp. Sig. (2-tailed) & & 1,222 \\
\hline
\end{tabular}

a. Test distribution is Normal.

b. Calculated from data. 
Tabel 3.

\section{Hasil Uji Autokorelasi}

Model Summary ${ }^{b}$

\begin{tabular}{|l|r|r|r|r|r|}
\hline Model & $R$ & $R$ Square & $\begin{array}{c}\text { Adjusted R } \\
\text { Square }\end{array}$ & $\begin{array}{c}\text { Std. Error of the } \\
\text { Estimate }\end{array}$ & Durbin-Watson \\
\hline 1 &, $300^{\mathrm{a}}$ &, 090 &, 043 &, 06615 & 2,050 \\
\hline
\end{tabular}

a. Predictors: (Constant), x4min_plagx4, x2min_plagx2, x1min_plagx1, x3min_plagx3

b. Dependent Variable: Ymin_plagY

\begin{tabular}{|l|r|}
\hline \multicolumn{2}{|c|}{ Runs Test } \\
\hline & $\begin{array}{c}\text { Unstandardized } \\
\text { Residual }\end{array}$ \\
\hline Test Value $^{\mathrm{a}}$ &, 00288 \\
Cases < Test Value & 41 \\
Cases > = Test Value & 42 \\
Total Cases & 83 \\
Number of Runs & 44 \\
Z &, 333 \\
Asymp. Sig. (2-tailed) &, 739 \\
\hline
\end{tabular}

a. Median

Tabel 4.

Hasil Uji Multikolonieritas

\begin{tabular}{|c|r|r|}
\hline \multicolumn{2}{|c|}{ Model } & \multicolumn{2}{|c|}{ Coefficients $^{\text {a }}$} \\
\cline { 2 - 3 } & Tollerance & \multicolumn{2}{|c|}{ VIF } \\
\hline (Constant) & & \\
x1min_plagx1 &, 964 & 1,037 \\
1 &, 956 & 1,046 \\
x2min_plagx2 &, 881 & 1,134 \\
x3min_plagx3 &, 887 & 1,128 \\
x4min_plagx4
\end{tabular}

a. Dependent Variable: Ymin_plagY

Tabel 5.

Hasil Uji Heterokedastisitas

\begin{tabular}{|c|c|c|c|c|c|c|}
\hline \multicolumn{7}{|c|}{ Coefficients $^{a}$} \\
\hline \multirow{2}{*}{\multicolumn{2}{|c|}{ Model }} & \multicolumn{2}{|c|}{ Unstandardized Coefficients } & \multirow{2}{*}{$\begin{array}{c}\begin{array}{c}\text { Standardized } \\
\text { Coefficients }\end{array} \\
\text { Beta }\end{array}$} & \multirow[t]{2}{*}{$\mathrm{t}$} & \multirow[t]{2}{*}{ Sig. } \\
\hline & & $\mathrm{B}$ & Std. Error & & & \\
\hline \multirow{5}{*}{1} & (Constant) & $-14,969$ & 7,169 & & $-2,088$ &, 040 \\
\hline & $\times 1 \mathrm{~min} \_$plag $\times 1$ &, 563 & 1,343 & ,047 & ,419 &, 676 \\
\hline & $\times 2$ min_plag $\times 2$ &,- 522 & 1,690 &,- 035 &,- 309 &, 758 \\
\hline & $\times 3$ min_plag $\times 3$ &,- 800 & ,926 &,- 102 &,- 864 & ,390 \\
\hline & $\times 4$ min_plag $\times 4$ & ,313 & ,222 &, 166 & 1,408 &, 163 \\
\hline
\end{tabular}

a. Dependent Variable: Ln_U2i 
Tabel 6.

\section{Hasil Uji Koefisien Determinasi}

Model Summary

\begin{tabular}{|l|r|r|r|c|}
\hline Model & $\mathrm{R}$ & $\mathrm{R}$ Square & \multicolumn{1}{|c|}{$\begin{array}{c}\text { Adjusted R } \\
\text { Square }\end{array}$} & $\begin{array}{c}\text { Std. Error of the } \\
\text { Estimate }\end{array}$ \\
\hline 1 &, $352^{\mathrm{a}}$ &, 124 &, 080 &, 06464898 \\
\hline
\end{tabular}

a. Predictors: (Constant), SIZE_x4, INDP_x2, INST_x1, KOMITE_x3

Tabel 7.

Hasil Regresi Linier Berganda

\begin{tabular}{|c|c|c|c|c|c|c|}
\hline \multicolumn{7}{|c|}{ Coefficients $^{a}$} \\
\hline \multirow{2}{*}{\multicolumn{2}{|c|}{ Model }} & \multicolumn{2}{|c|}{ Unstandardized Coefficients } & \multirow{2}{*}{$\begin{array}{c}\text { Standardized } \\
\text { Coefficients } \\
\text { Beta } \\
\end{array}$} & \multirow[t]{2}{*}{$\mathrm{t}$} & \multirow[t]{2}{*}{ Sig. } \\
\hline & & $\mathrm{B}$ & Std. Error & & & \\
\hline \multirow{5}{*}{1} & (Constant) &,- 053 &, 154 & &,- 342 & ,733 \\
\hline & INST_x1 & ,063 &, 037 &, 181 & 1,690 & ,095 \\
\hline & INDP_x2 &,- 013 &, 047 &,- 029 &,- 272 & ,786 \\
\hline & KOMITE_x3 & ,059 & ,026 & ,264 & 2,275 & ,026 \\
\hline & SIZE $\times 4$ & ,003 & ,006 & ,049 & ,430 & ,669 \\
\hline
\end{tabular}

a. Dependent Variable: ETR_y

Tabel 8.

Hasil Uji Statistik F

\begin{tabular}{|c|c|c|c|c|c|c|}
\hline \multicolumn{7}{|c|}{ ANOVA $^{a}$} \\
\hline & & Sum of Squares & df & Mean Square & $\mathrm{F}$ & Sig. \\
\hline \multirow{3}{*}{1} & Regression & ,047 & 4 & \multirow{3}{*}{$\begin{array}{l}012 \\
, 004\end{array}$} & \multirow[t]{3}{*}{2,798} & \multirow[t]{3}{*}{, $031^{b}$} \\
\hline & Residual & ,330 & 79 & & & \\
\hline & Total & ,377 & 83 & & & \\
\hline
\end{tabular}

a. Dependent Variable: ETR_y

b. Predictors: (Constant), SIZE_x4, INDP_x2, INST_x1, KOMITE_x3 